\title{
Parenting Skill untuk Meningkatkan Kepedulian Orang Tua dalam Parenting Education di SD 19 Parambahan
}

\author{
Sri Putri Rahayu Z \\ IAIN Batusangkar \\ Email: sriputrirahayu@iainbatusangkar.ac.id
}

\begin{abstract}
Parenting is a very big influence on children's growth and development, both in the physical, linguistic, social, emotional and cognitive aspects of children, besides parenting also affects the behavior and achievement of children in school. Inappropriate parenting towards children will cause various problems in children ranging from behavioral problems, social relationships, emotional problems, and academic problems while the right parenting will make children grow and develop according to the stage of development. The purpose of this community service activity is that parents at SDN 19 Parambahan can find out the right care for children in accordance with the stages of child development. This activity was carried out using lecture, film analysis and answer methods. This activity was considered successful because based on the results of the interview the parents stated that there was a lot of knowledge they gained during the activity, because most of them had never received parenting skills before.

Keywords: Parenting, Parents, Elementary school
\end{abstract}

\begin{abstract}
ABSTRAK
Pola asuh orang tua (parenting) merupakan hal yang sangat besar pengaruhnya terhadap tumbuh kembang anak, baik pada aspek fisik, bahasa, sosial, emosi dan kognitif anak, selain itu pola asuh juga berpengaruh pada perilaku dan prestasi anak disekolah. Pola asuh yang tidak tepat terhadap anak akan mengakibatkan berbagai masalah pada anak mulai dari masalah perilaku, hubungan sosial, masalah emosi, dan masalah akademik sedangkan pola asuh (parenting) yang tepat akan menjadikan anak tumbuh dan berkembang sesuai dengan tahap perkembangannya. Tujuan dari kegiatan pengabdian masyarakat ini agar para orang tua di SDN 19 Parambahan dapat mengetahui cara pengasuhan yang tepat terhadap anak sesuai dengan tahap perkembangan anak. kegiatan ini dilakukan dengan metode ceramah, analisis film dan tannya jawab.kegiatan ini dianggap berhasil karena berdasarkan hasil wawancara orang tua menyatakan banyak ilmu yang mereka dapatkan selama kegiatan, karena kebanyakan dari mereka tidak pernah mendapatkan parenting skill sebelumnya.
\end{abstract}

Kata kunci: pengasuhan, orang tua, sekolah dasar 
Sri Putri Rahayu Z

\section{PENDAHULUAN}

Keluarga merupakan tempat pendidikan pertama dan utama bagi seorang anak. Nilai-nilai pengasuhan yang diterapkan keluarga akan mempengaruhi tubuh kembang anak hingga dewasa nantinya. hal ini senada dengan yang dikemukakan oleh Kilonzo (2017) yang menyatakan gaya pengasuhan dalam keluarga memiliki arti penting dalam kehidupan anak. pola asuh orang tua (parenting) merupakan interaksi antara anak dan orang tua selama mengadakan kegiatan pengasuhan. Pengasuhan ini berarti orang tua mendidik, membimbing, dan mendisiplinkan serta melindungi anak untuk mencapai kedewasaan sesuai dengan norma-norma yang ada dalam masyarakat (Shochib, 2010).

Menurut Baumrind mengungkapkan ada empat macam pola asuh orang tua yaitu: (1). Pola Asuh otoritarian, adalah gaya pengasuhan yang membatasi dan menghukum. Orang tua meminalisir perdebatan verbal dan menerapkan batas dan kendali yang tegas pada anak. memaksa aturan secara kaku tanpa kejelasan. Dampak dari pola asuh otoritarian jika diterapkan secara berlebihan akan membuat anak tidak bahagia, ketakutan, minder, memiliki sikap acuh dalam belajar, pasif, dan memiliki kempuan komunikasi yang lemah. (2). Pola asuh otoritatif, yaitu Pola asuh yang mendorong anak untuk mandiri namun masih menerapkan batas kendali pada tindakan mereka. Adanya kontrol atas tindakan anak akan membentuk peningkatan prestasi dan 26 pengawasan dalam belajar anak, dimana anak akan merasa didampingi dan diberi perhatian. (3). Pola Asuh yang Mengabaikan adalah gaya pengasuhan dimana orang tua sangat tidak terlibat dengan anak. Anak yang memiiliki orang tua mengabaikan cenderung memiliki prestasi belajar yang rendah dan 27 tidak memiliki kemampuan sosial. Banyak diantaranya memiliki pengendalian diri yang buruk dan tidak mandiri. Mereka sering kali memiliki harga diri yang rendah, tidak dewasa, dan mungkin terasing dari keluarga, dalam masa remaja, mereka mungkin menunjukkan sikap suka membolos dan nakal maka dari itu, dikarenakan kurangnya perhatian dari orang tua mengakibatkan nilai belajar anak menjadi menurun. (4) Pola Asuh yang Menuruti adalah gaya pengasuhan di mana orang tua sangat terlibat dengan anak, namun tidak terlalu menuntut dan mengontrol mereka. Orang tua menuruti cenderung membiarkan anak melakukan apa yang diinginkan. Hasilnya, anak tidak pernah belajar mengendalikan perilakunya sendiri dan selalu berharap mendapatkan keinginannya. Anak yang memiliki orang tua yang selalu menuruti cenderung mempunyai pengendalian diri yang kurang (tidak bisa megatur jadwal belajar, tidak bisa mengendalikan emosi), kurangnya pengendalian diri akan mempengaruhi prestasi belajarnya (Santrock, 2007).

Pola asuh yang baik, tentu akan menghasilkan anak-anak yang sesuai dengan tahap perkembangannnya, baik itu pada aspek fisik, bahasa, sosial, emosi, maupun aspek kognitif yang berhubngan dengan prestasi anak disekolah. sebaliknya pola asuh yang buruk akan membuat berbagai macam permasalahan anak seperti masalah perilaku, emosi yang tidak terkendali, tantrum, permasalahan dalam menjalin hubungan sosial yang baik dengan teman sebaya dan permasalah akademik disekolah. Hubungan orangtua dan anak yang positif adalah dasar dari lingkungan rumah dan sekolah yang sehat. Sikap suportif, perhatian, dan fleksibel dari orang tua menghasilkan psikologis, anak-anak yang sehat secara mental (Bibi, Chaudhry, Awan dan Tariq, 2013).

Berdasarkan hasil penelitian Kordi \& Baharudin (2010) Terdapat hubungan antara gaya pengasuhan dengan prestasi belajar anak disekolah. gaya pengasuhan 
sangat memengaruhi pemahaman, sikap, dan prestasi anak disekolah (Hendyanti, Sudarmianti, Utaya (2016), Rizki, Susilawati, \& Mariam (2017), Musaheri (2007)), dan Anak-anak dari orang tua yang lalai sering kesulitan dalam disiplin diri dan memiliki hasil yang buruk di sekolah dibandingkan dengan siswa yang lainnya (Kassahun, 2010).

SDN 19 Parambahan merupakan salah satu SDN Negeri yang terletak di nagari Parambahan Kabupaten Tanah Datar, Propinsi Sumatera Barat. Sebagai salah satu SDN yang terletak di daerah, orang tua / wali murid SDN 19 Parambahan jarang sekali mendapatkan pelatihan parenting baik dari nagari ataupun dari sekolah sendiri, pelatihan parenting dilakukan supaya orang tua mengetahui cara pengasuhan anak yang tepat sehingga sejalan dengan visi misi sekolah dalam mencapai tujuan pendidikan.

\section{METODE PELAKSANAAN}

Tempat pelaksanaan kegiatan adalah di SDN 19 Parambahan, kabupaten Tanah Datar, Propinsi Sumatera Barat. Kegiatan parenting skill ini dilaksanakan pada tanggal 28 November 2019 dengan metode ceramah, analisis film pendek dan tannya jawab. Secara garis besar, materi parenting skill meliputi (1) Prinsip pengasuhan (2) Tiga pilar dalam menjaga potensi baik anak dalam pengasuhan. (3) prinsip pengasuhan (4) kesalah-kesalah parenting yang dapat merusak tumbuh kembang anak (5) proses pembentukan karakter (6) cara mengatasi permasalahan-permasalahan anak (7) Pengasuhan pada anak milenial (berkenaan dengan penggunaan gadget pada anak SD).

\section{TEMUAN DAN DSKUSI}

Temuan yang didapat dari pengabdian masyarakat yang bertemakan parenting skill untuk meningkatkan kepedulian orang tua dalam kegiatan parenting di SDN 19 Parambahan yaitu: berdasarkan hasil observasi para orang tua sebagai peserta kegiatan terlihat antusias dan memiliki minat yang tinggi dalam mengikuti kegiatan ini ditunjukkan dengan keaktifan peserta didalam ruangan dan tidak adannya orang tua yang meninggalkan ruangan selama kegiatan berlangsung.

Berdasarkan hasil evaluasi setelah pelaksanaan kegiatan ini, dari hasil wawancara didapatkan bahwa peserta merasakan manfaat yang besar dari kegitan yang dilakukan. Melalui kegita parenting skill, orang tua mengetahui bagaimana cara teknik parenting yang tepat untuk anak, dan mengetahui penyebab permasalahan perilaku, sosial, emosional dan masalah akademik pada anak. orang tua juga mengetahui dampakdampak kesalahan parenting terhadap tumbuh kembang anak, seperti dampak dari kekerasan fisik dan psikis, modeling anak terhadap perilaku orang tua yang buruk, pujian yang berlebihan pada anak, terlalu memanjakan anak ataupun dampak dari pengasuhan otoriter orang tua terhadap anak. orang tua juga mengetahui cara mengatasi permasalahan-permasalahan pada anak, dan orang tua mengetahui adanya pilar-pilar untuk menjaga potensi anak dalam pengasuhan. Orang tua menyatakan mereka mendapatkan banyak pengetahuan ketika mengikuti kegitan ini dan bertekat untuk merubah pola asuh yang salah yang pernah mereka lakukan dalam pengasuhan. Pihak sekolah juga mengatakan kegiatan parenting skill ini sangat bermanfaat dan berharap kegiatan serupa dapat dilakukan lagi di SDN 19 Parambahan. 


\section{Sri Putri Rahayu Z}

Terselenggarannya kegiatan ini tentunya tidak terlepas dari beberapa faktor penghambat seperti ditengah acara pengeras suara atau mikrofon tiba-tiba rusak dan diganti dengan mikrofon cadangan. Anak-anak yang juga ingin ikut dalam ruangan bersama orang tua ketika jam istirahat sehingga kegiatan dihentikan sebentar sampai guru dan panitia mengkondisikan anak-anak untuk bermain diluar. Tidak adanya Aula di SDN 19 Parambahan sehingga keberlangsungan kegitan ini disiasati dengan membuka pembatas 3 buah kelas menjadi satu ruangan yang cukup besar.

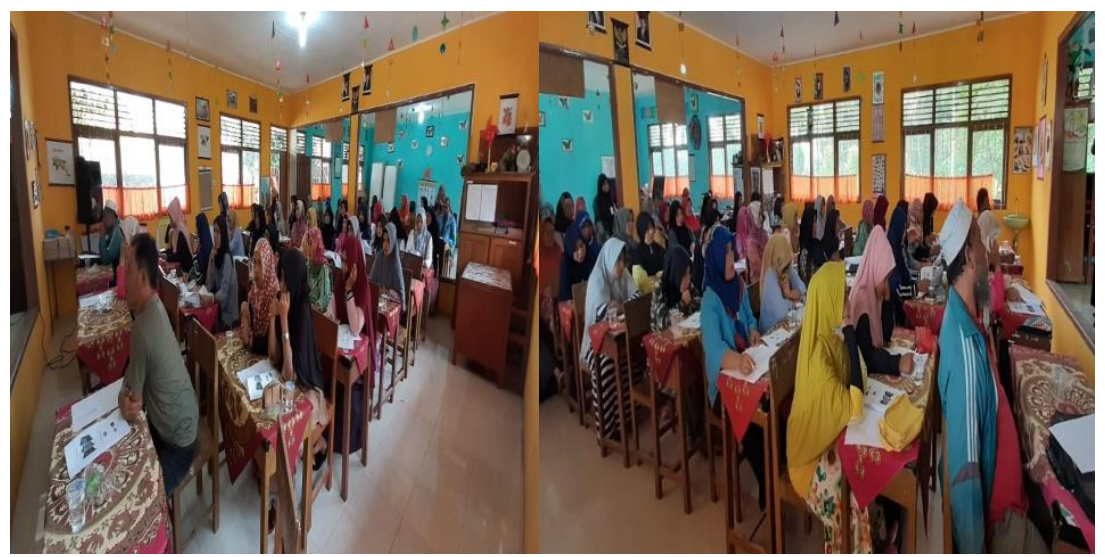

Gambar 1. Rangkaian Pelaksanaan Kegiatan Parenting Skill

\section{KESIMPULAN}

Kegiatan parenting skill ini diangap berhasil dilakukan karena memberikan manfaat bagi peserta kegiatan. Orang tua atau wali murid SDN 19 Parambahan mengetahui cara parenting yang tepat terhadap anak dan dampak pengasuhan terhadap anak terutama pengasuhan terhadap anak di zaman milenial ini yang dekat dengan perkembangan teknologi yang sudah berbeda dengan pengasuhan-pengasuhan terdahulu.

Adapun saran-saran bagi berlangsungnya kegiatan serupa yang berhubungan dengan parenting skill dapat dilakukan pada orang tua di PAUD/ TK, SMP dan SMA, karena setiap tahap perkembangan tentu memiliki cara pengasuhan yang berbeda, dan pada orang tua yang telah mengikuti kegiatan parenting diharapkan dapat menyebarluaskan pengetahuannya mengenai parenting pada sanak keluarga lain di rumah.

\section{UCAPAN TERIMA KASIH}

Ucapan terimakasih disampaikan kepada SDN 19 Parambahan, Kabupaten Tanah Datar dan IAIN Batusangkar untuk kerja sama dan dukungannya baik secara moril maupun materil dalam kegiatan pengabdian masyarakat ini.

\section{DAFTAR RUJUKAN}

Bibi, F., Chaudhry, A,G., Awan, E,A., \& Tariq, B. 2013. Contribution of Parenting Style in life domain of Children. Journal Of Humanities And Social Science (IOSR-JHSS). Volume 12, Issue 2. PP 91-95 e-ISSN: 2279-0837, p-ISSN: 2279-0845. 
Hendyanti, w., Sudarmianti., \& Utaya, S. 2016. Pengaruh Pola Asuh Orangtu A Terhadap Prestasi Belajar Ips Melalui Motivasi Belajar (Studi Pada Siswa Kelas Iv, V, Vi Gugus 2 Kecamatan Ngantang Kabupaten Malang). Jurnal Pendidikan . Volume: 1 Nomor: 5. EISSN: 2502-471X.

Kilonzo, P.M. 2017. The Impact Of Parenting Styles On Personality Dimensions Of Adolescents In Public Secondary Schools: A Case Of Mombasa County, Kenya. International Journal of Education and Research. Vol. 5 No. 7 .ISSN: 2411-5681.

Kordi, A \& Baharudin, R. 2010. Parenting Attitude and Style and Its Effect on Children's School Achievements. International Journal of Psychological Studies. Vol. 2, No. 2. ISSN 1918-7211 E-ISSN 1918-722X.

Milevsky, A., Schlechter, M., Netter, S., \& Keehn, D. (2007). Maternal and paternal parenting styles in adolescents:associations with self-esteem, depression and life-satisfaction. Journal child family study. 16, 39-47. doi: 10.1007/s10826006-9066-5.

Musaheri. 2007. Pengantar Pendidikan. Yogyakarta: IRSiSoD.

Rizki, S,D., Susilawati, \& Mariam, I. 2017. Hubungan Pola Asuh Orang Tua Dengan Prestasi Belajar Anak Usia Sekolah Dasar Kelas II dan III. Jurnal Keperawatan. Volume 8, Nomor 1. P- ISSN: 2086-3071, E-ISSN: 2443-0900

Santrock, John W.2007. Adolescence. 11 th edition. New York: McGraw-Hill Companies, Inc

Shochib, M. 2010. Pola Asuh Orang Tua dalam Membantu Anak Mengembangkan Disiplin Diri. Jakarta: Rineka Cipta. 